\title{
Speaking for the Soviet land. Voice and mediated communities in the age of early broadcast
}

\author{
Dmitri Zakharine* \\ Department of Sociology and History, University of Constance, Konstanz, Germany
}

\begin{abstract}
Following the concept of mediatization as an interweaving between technological change and social change, the study will specifically apply it to the relation of gender and political communities to the broadcast culture of Soviet Russia. Given its enormous size, cultural heterogeneity and religious diversity, Russia had every reason to assign special value to the efficiency of broadcast communication networks. By analyzing regulatory frameworks for broadcasting voices of popular film actors, announcers and representatives of power, the article singles out the features of Soviet broadcasting set in deliberate contrast to the broadcast cultures of Western countries.
\end{abstract}

Keywords: mediatization; Soviet Union; gendered voice; cinema; broadcasting

\section{Mediated voices and mediated communities}

Recorded and electronically synthesized voices are technically produced in such a way that listeners get the impression of authentic human voices. However, it would be a mistake to assume that mediated voices have the same acoustic and social properties as natural voices. In designing an appropriate voice for broadcast, sound directors have to recreate everything that an ordinary voice displays. This encompasses relations between pitch and gender (vocal folds of men are longer and their voices are lower than those of women), timbre and life style (a rough voice allows to identify a habitual smoker), amplitude and social status (authorities do not exert themselves to speak louder in order to be heard), breath and mood (controlled breathing is at odds with an erotic mood, which is characterized by a release and yielding), pronunciation and ethnic background (Russians from the South say H whereas Russians from the North say G) and so on (Gradoll \& Swann, 1989, pp. 22-23). The difference between natural voices and mediated voices refers to the semiotic distinction between regulative and constitutive rules to be used for the construction of meaning. While regulative rules define acoustic differences between two voices, constitutive rules determine what social conditions exist if you record, edit, reproduce or transmit a voice. The rules for the voice design that were implemented in the Soviet radio and sound film production, differed fundamentally from the rules used by that time in British and German broadcasts.

The first set of differences concerned elaborate voices of the salon. Given the underdevelopment of the bourgeois class in Russia, the salon-type speech was basically restricted to the lifestyle of St. Petersburg and Moscow elites. When the expert for Russian stage pronunciation

*Email: zakharine@list.ru 
Prince Sergei Volkonsky complained that "our female voices are mostly too high", he was referring to the voices of the bilingual French-Russian-speaking aristocracy. The prince allegedly got earache listening to Alexander Taneyev's one-act opera "Cupid's Revenge" (1899), whose scenery indicated the foreign origin of the Russian salon: trees adorned with flourishes in French rococo park style served there as the stage backdrop (Volkonsky, 1913, p. 74). In 1913, the Russian population mainly consisted of peasants who lacked any social resources for promoting highpitch female voices. The vocal culture of the thin nobility stratum was swept off the social stage after the October revolt in 1917, and Prince Volkonsky had to immigrate to Paris after being imprisoned several times by Bolsheviks.

The second set of differences concerned the interrelationship between written and oral cultures. Communicative patterns shared by Russian peasants had mainly an oral structure. According to Ong, the predominance of orality in communication implies a poor ability of the community to reproduce knowledge. For example, oral communication is suitable neither for storing information nor for repeating intellectually challenging utterances in the same wording several times (Ong, 1982, p. 11). Referring to oral communication as a basis of collective identity, the pre-revolutionary educators in Russia required a radical reorientation of language teaching toward the acquisition of oral language skills. They advocated a natural not elaborate peasant's voice as a "teaching voice of the entire nation", and they stood up "for the protection of the living word" (Chernyshev, 1912, p. 24). At the time of radiofication, the culture of Soviet broadcast (or the culture of "secondary orality", to use Ong's definition) still preserved many features of the Russian primary oral culture. Like no other type of orality, the secondary orality established by Soviet broadcast served the power of the moment. And like no other radio culture, the Soviet radio was set to reproduce voices that were determined to correspond to acoustic experiences of the extended rural family. This sort of community - not as a biologically determined network of relationship but rather an identity construct - had essentially determined the experience of Soviet radio listeners who associated leaders' voices with natural voices of family elders. This explains the preponderance of lisping, hissing, spluttering and rhetorical impotence typical for the Soviet leaders of 1930-1999 (starting with Joseph Stalin, Nikita Khrushchev, Georgii Malenkov, Leonid Brezhnev, Nikita Podgorny, Konstantin Chernenko and ending with Mikhail Gorbachev, Viktor Chernomyrdin and Boris Yeltsin).

The third set of differences concerned the vocal representation of sacred power. The sacralization of Russian Czar can be traced back to the end of the seventeenth century when Czar Alexei Romanov ordered an orb and diadem in order to indicate his similarity with the devout Greek emperor Constantine. In the panegyric literature of the mid-seventeenth century, the Czar began being referred to as "sacred" (Russian: svyatoy) and as a "God on earth" (Russian: zemnoy bog) (Savva, 1901, p. 147; Uspensky \& Zhivov, 2004, pp. 132-151). The Russian court was regarded as a holy place where talking was forbidden: particularly in the presence of the Czar one had to be silent. Sacred Silence (Latin: sacro sanctum silentium) accompanied meetings of the Old Russian parliament (Zakharine, 2005, p. 386). Until the last crisis of Russian monarchy in February 1917, Czars usually met elected officials without making any speeches themselves. Similarly to the kings and queens of United Kingdom and the emperors of Germany, Russian Czars did not regard staying in front of the microphone as an obligatory part of their political self-presentation. Soviet state leaders have inherited and preserved this wary relationship to public speaking. During the Soviet period of Russian history, the ruling class knew little about standard Russian pronunciation and possessed hardly any rhetorical skills. In fact, despite the early spread of sound reproduction technology in Soviet Russia, only between 10 and 15 speeches by Lenin (total duration - 45 minutes) have been recorded (Skorokhodov, 2004, p. 448; Volkov-Lanit, 1939, p. 9). A number of speeches pronounced by secondary members of the Bolshevik Politburo such as Mikhail Kalinin, Lazar' Kaganovich and Kliment 
Voroshilov survived on disc, but Lev Trotsky' s public speaking was only recorded once. The difference between 117 speeches by Winston Churchill recorded in the UK and only 13 speeches of Joseph Stalin surviving in Russian audio-archives is telling indeed.

The fourth group of differences refers to the verbal scarcity of Russian Orthodox Church. Beyond the performance of state ceremonials, Russian Orthodox Church was extremely cautious concerning the tradition of Roman eloquence. The persistence in the belief that the perception of God's message is pre-reflective and spontaneous was preventing (and is still preventing) Russian Orthodox Church from having Holy Scriptures translated from Church Slavonic into vernacular Russian (Uspensky, 1988, pp. 208-224). Hiding over the centuries behind religious dogmas, political authorities were represented in public situations by low-rank appointees speaking on their behalf.

The fifth group of differences is the imperial language policy of the Tsarist Empire whose state elites could not hope to impose a perfect Russian pronunciation on the Turkish, Caucasian and Finno-Ugric ethnic groups. On the eve of the October Revolution Russian theater managers complained that even the standard speech patterns of dramatic actors in the St. Petersburg and Moscow theaters were too colorful and rough. An expert on stage pronunciation Ozarovsky (1900) observed that it would not be easy to determine which dialect prevails in one or another Russian theater troupe, because dialect variance became contaminated with role differences in the repertoire: While a "Father" and a "Dandy" try to give their pronunciation the character of a colorless Petersburg accent, an "Ingénue" twitters in the upper pitches with a southern dialect, a "Fool" and a "Funny Old Lady" fashion their pronunciation in the style of a Muscovite everyday chat, and a passionate "Jeune Premier" always makes guttural cracking sounds disclosing his Jewish origin (Ozarovsky, 1900, p. 6). A crucial prerequisite for the establishment of the radio voice culture would have been standardization of verbal expression on the basis of urban Russian. For such standardization, however, neither technical nor social conditions obtained until the violent industrialization and the forced expansion of education in 1920s-1930s took place.

\section{Implementing the living word}

The spread of radio was tied to the idea of sound amplification that extended speech in space. Starting from the third quarter of the nineteenth century, the microphone use established itself as a technique of crowd manipulation. With a loudspeaker, a single person could speak simultaneously to hundreds and even thousands of listeners. The advent of voice reproduction was anticipated by the new character of state power that faced a rapid influx of rural population into towns in the second half of the nineteenth century. It is hardly surprising that the early theories of propaganda which compared public speaking to taming wild beasts (cf. Le Bon 1905 and Bernays, Propaganda: The formation of men's attitudes (1923), have foretold the use of loudspeakers for the purpose of crowd manipulation.

Comparing the spread of broadcast voices across the globe, one may conclude that the distribution of radio and sound film took place almost synchronously in the West and the East. In 1916, de Forest broadcast the first American advertisements and the first Presidential election campaign for Charles Hughes and Woodrow Wilson. However, regular radio transmissions began in the USA in the 1920s - approximately at the same time as it happened in Germany, Great Britain and the Soviet Union. By most accounts, the first radio station in Germany (supervised by the Post Office) went on the air in Berlin in late 1923. The BBC radio services began in 1922, and Soviet experiments with transmitting and receiving human speech started around 1921. Two engineers from Kazan, Uglov and Dikarev, were awarded a contract by the Soviet government for constructing a sound amplifier and a loudspeaker as part of the effort to realize Lenin's 
concept of "Radiogazeta". On 8 June 1921, loudspeakers of this type were installed in six squares throughout Moscow.

Notwithstanding the mentioned parallelism of radio revolutions in the West and East, it is obvious that the implementation of radio technologies did not happen everywhere in the same way. The difference pertained to the realization of the both fundamental ideas of radio: establishment of control over space on the one hand, and transmitting particular sound patterns set to meet the needs of listening communities, on the other. Defining the Soviet radio as a newspaper without paper and without distance, Lenin was calling for rapid modernization that was easier said than done (Lovell, 2015).

Neither the density of the Soviet radio networks nor the clarity and loudness of sound in 19221930 was hardly up to the German, American and British level. A survey about the state of Soviet radio networks published in a popular radio magazine Radioslushatel (Radio listener) described the radiofication of only $50 \%$ of households in towns and $30 \%$ in the countryside as a utopian dream (1930). To be realized, according to the author of the survey, this would have required the installation of 3,200,000 receivers in towns and 8,000,000 receivers in the countryside. Instead of the required number of $13,000,000$ receivers, however, only 400,000 receivers $(0.3 \%$ of the required amount) were available. About 141,000 peasants who represented $83 \%$ of Russian population could boast only 40,000 receivers (one receiver per 3500 peasants). At the same time the $5 \%$ of all households in Great Britain and $16 \%$ of all households in the USA were equipped with radio receivers (Anonymous, 1929).

\section{НАДЕЖНАЯ СЈЫШИМӦСТЬ НА ДЕТЕКТОРНЫЙ ПРИЕМНИК}

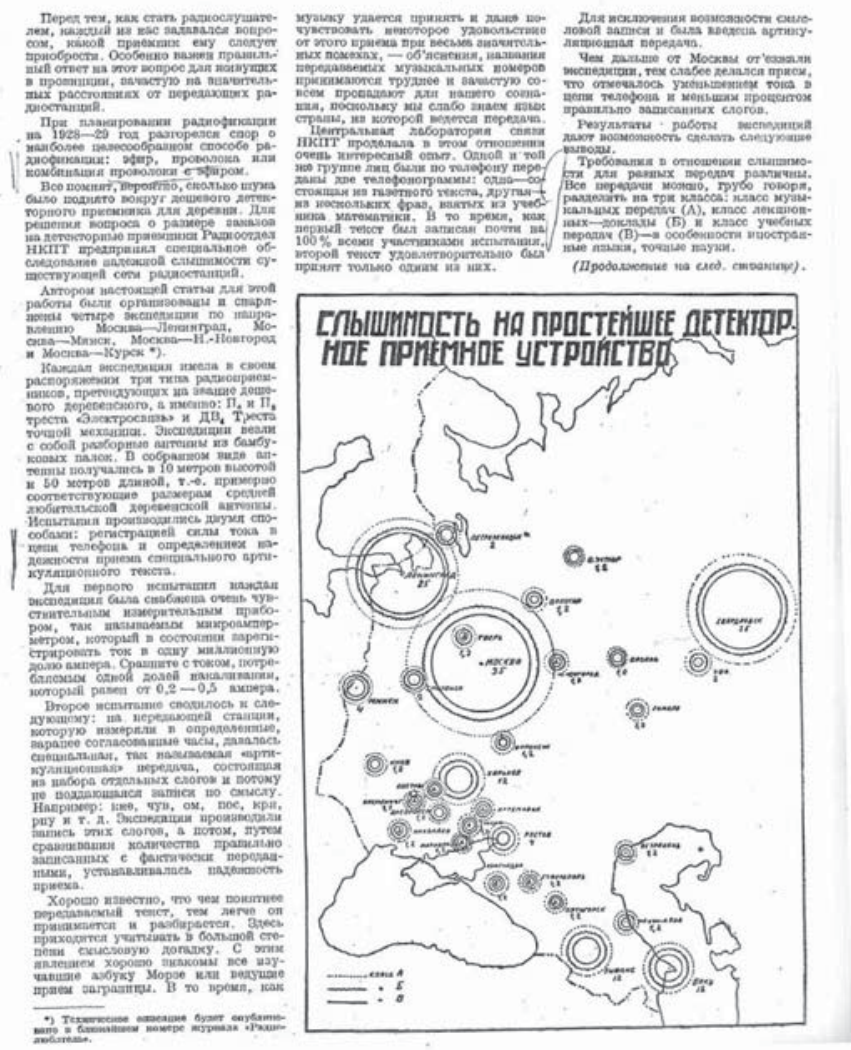


The map above drawn by Soviet radio researchers demonstrates that no radio messages transmitted from Sverdlovsk (Ural Mountains) by means of a cheap wireless radio could be received in Moscow. According to the report from 21 May 1929, 52\% of all radio receivers were self-made devices. The audible threshold is marked with a straight line for music, with a wave line for reports on trivial matters, and a dotted line for texts in foreign languages and scientific texts. One can conclude that the maximum distance for music transmissions was only 392 kilometers: Music transmitted from Moscow could not be heard in Sankt-Petersburg. One should also take into account that $99 \%$ of Soviet radio stations possessed a lower capacity than the so-called Komintern radio station in Moscow. In Radioslushatel it was pointed out that foreign transmitters provided a better quality of reception even if they possessed a lower capacity than the analogous devices in Russia (1929). Russian devices, writes the author of the survey, are less capable of resisting interference: That is why a Warsaw radio station that had a capacity of 12 kilowatt was reportedly better heard in Moscow than the Moscow station Komintern with its 40 kilowatt.

One can conclude that the plan to maintain the ideological control over the Soviet space was doomed to failure from the very beginning. The competition with technologically higher developed "hostile states" that surrounded Soviet Russia after the October Revolution of 1917 was now extended into the virtual world of radio communication, and the style of Soviet radio programs was shaped by ongoing effort to win this race. Considering three main types of sound media such as music, speech and soundscape, we may see that unlike British Broadcast Corporation, the Soviet Radio was rather short of music transmissions. According to Doctor (1999, p. 24), music accounted for nearly two-thirds of the daily output of BBC (166 hours out of 249 hours of the overall broadcast); less than a fifth was devoted to classical music while two-thirds were given to popular genres. This was quite different in the Soviet Union where $50 \%$ of all transmissions were speech-based political reports, $30 \%$ speech-based scientific reports and just $20 \%$ the so called "artistic programs" that could include music. Essentially, the culture of Soviet broadcast was based on speech - or voice.

According to Wittlinger and Sendlmeier (2005) it makes sense to divide the voice types of radio and television speakers into three categories: of news broadcasters (announcers), radio hosts (moderators) and VIPs such as executive authorities, political leaders, prominent actors, etc. Each of these vocal repertoires is characterized by a particular semiotic structure and its role in social context. The voice standard of radio announcement has its roots in the European tradition of messengers who were predominantly males. In the early days of radio, the listeners' resistance to female voices was extremely strong, particularly in the field of news broadcasting. When the American radio station WJZ conducted a survey of 5000 listeners in 1926, it became apparent that 100 of 101 participants preferred the voices of male news announcers (Hilmes, 1997, p. 141). In the Soviet context, the resistance was even stronger: in the early days of Soviet broadcast, the first chief editor of Radiogazeta Gosta Alexander Gurin signed a number of directives that required removing of all female voices from the air. Only in 1929 four women - Valentina Solovyova, Anastasia Golovina, Natalia Tolstova and Olga Vysotskaya were appointed as announcers. However, their activity was mostly confined to moderating children and housewife programs. On the top of that, even female announcers talking to female listeners were expected to possess low pitch voices with a frequency value of 150 instead of customary 200 Hertz.

From its very beginning, the Soviet radio was promoted as the prefect medium for open political discussions: both scientists and journalists who wrote about the political perspectives of voice transmission had no doubt that the Soviet party officials would use radio and sound film to communicate freely with the masses according to the pattern of American politicians: 
We can say with fullest confidence that with the advent of sound film, the appearance of our political leaders and great scholars is made possible in all godforsaken places of the Soviet Union and will awaken the social and political life there.

wrote Soviet film scientist Nicolai Anoshchenko in his pioneering comparative study Sound film in our country and abroad (1930).

Sound film which gives another impressive effect as compared to the radio (namely the combination of image and sound) has one big advantage over radio: the possibility to listen to the same person in different places of the Soviet Union. This has already been recognized outside of Russia. There (e.g. in America) we see how sound film was used during the presidential election. Hoover and Smith addressed their voters with flaming speeches [on sound film]. (p. 2)

But the idea of broadcasting live events with the leaders of the Soviet state was only partially fulfilled. The first recording of Stalin's speech (14 May 1935) took place long after the advent of optical sound recording (1928). Prior to that, recordings of Stalin were practically banned. The 1935 recording took place at the request of the executive producer for the Soviet Film monopoly, Boris Shumiatsky (who was subsequently arrested and executed in 1938). According to the eyewitnesses, Stalin was appalled and disconcerted when he discovered that his voice was recorded during his speech to the party's general assembly. Leonid Kozlov remarks that Stalin felt uncomfortable because of his strong Georgian accent. Besides, the temporal and spatial separation of his voice from the body might have put the charisma of the Red Czar in doubt (Kozlov, 1996, p. 77).

In the 1930s, the need for speaker training was used as a pretext for the banishment of the uncertain microphone voices from radio. From now on, the spontaneity of oral forms of expression was to be simulated by the alleged exclusion of the written text, with the invisible speaker reading from written text as before. Like no other European radio culture of the 1930s, the Soviet radio culture stressed voice training of the speaker. Before and during World War II, the trained voice of radio announcer Yuri Levitan from the Soviet Information Bureau was associated with the voice of the central power, the voice of Stalin (Taranova, 2010). From a psychoacoustic perspective, the secret of the effect of Levitan's voice lay in the bright area of the overtones. While the highest overtones of his voice were in the soprano range, the spectrum of low frequencies was dominated by deep bass tones. The frequency spectrum of Levitan's voice had a certain similarity to the spectrum of deep metallic tones. The voice of the first radio announcer in the country was the voice of metal, cast iron and steel. It alluded to the material, which symbolized the victorious era of Soviet industrialization. During World War II, a reward of 250,000 Reichsmarks was offered by the German propaganda minister Joseph Goebbels, "for any German hero that would capture Levitan and bring him alive to Berlin", After Goebbels' plan, the eloquent Jew was to proclaim the ultimate German victory at Christmas 1941 in Berlin. When such victory seemed out of reach, SS Special Forces swarmed out to liquidate the radio announcer. The Soviet Radio Agency was bombed in particular at those times when Levitan was reading radio news broadcasts. In a secret operation, the owner of the treasured voice familiar to the entire country had to be evacuated to Ekaterinburg in the Urals.

The early practice of radio voice training has been anticipated by pre-Soviet research on speech intonation, pronunciation and rhythm. Whereas some applicable data came from linguistic research on Russian dialects, the theoretical underpinning originated in music and song theory. A detailed classification had been worked out in the studies on vocal acoustics based on the theory of the French pedagogue François Delsarte. The system, which Prince Sergei Volkonsky presented in his work The expressive power of the word takes into account categories such as (1) pitch; (2) "force vs. volume" of the voice (the study presents a distinction between the tension of the laryngeal muscles and the effect of voice volume); (3) the "quality" of the voice (i.e. the 
interaction of emotions and vocal registers) and (4) "voice leading" (intonation or pitch change from sentence to sentence). This early research on vocal acoustics contained the first still rather imperfect results of rudimentary measurements, which however, provided an important basis for the subsequent voice recordings (Volkonsky, 1913, pp. 74-105). For example, Volkonsky used the general scheme of musical intervals such as second, third, fifth and octave for a rough qualitative analysis of the voice level change in the Russian spoken language. He was able to present the formulas of Russian intonation as follows: The second gives the speech "the character of a serene self-control and dignity". The intonation of a question uses such intervals as the third, fifth and octave. A question intoned in the third interval conveys quiet curiosity, the fifth interval intonation communicates astonishment and a question intoned in the octave interval expresses surprise. A new Darwinian orientation of Russian language theory, as articulated in such approaches as The physiology of the all Russian pronunciation by Vasily Bogoroditsky (1909) or The physiology of slavonic speech by Olaf Broch (1910) implicated a radical reinforcement of the iconic aspect of sound semantics. In fact, it was a recursive animation of the sounds of a national language that were henceforth treated as direct providers of physiological stimuli). S. Krassovsky, for example, answering the question about the relation of "emotional sensations" to "articulated sounds", claimed that "K" signals the "awareness of danger", whereas "W" means the "movement into the interior of the other object" (1906, p. 66). The findings of speech revolutionaries also implied a rather bold association of tooth and lip sounds with the teeth being a primordial weapon against an external threat.

In the context of reflections on the primary oral lore as a basis of Russian community, the role of Soviet educational centers that were dealing with techniques of public speech appears to be particularly symptomatic. In 1918, soon after the October revolt, the theater scholar Vsevolod Vsevolodsky-Gerngross succeeded to establish the Institute of the living word with the support of Lenin's government (Chown \& Brandist, 2007, p. 2). It should be noted that only $64.5 \%$ of the students had secondary school certificates, $21.4 \%$ possessed university degrees and $1.4 \%$ had proof of completed home education (Zapiski Instituta Zhivogo Slova, 1919, vyp. 1, 14). People's Commissar for Educaion, Anatoly Lunacharsky, was among the first guest professors of the institute. At the suggestion of the musicologist Valerian Bogdanov-Berezovsky, lectures on the psychology of hearing were added to the program of the institute. Following up on the physiological approaches of Broch and Bogoroditsky, Yakubinsky prepared a series of lectures for the Institute of the Living Word (1919).

In his research on intonation of the Russian spoken language (1922) Vsevolodsky-Gerngross used measuring units based on Sergei Volkonsky's research carried out before the October Revolution. These units delivered important prerequisites for the calculation of the sound pressure of microphone voices. For example, the pressure of the air that is exhaled in the flow of speech was measured by Vsevolodsky-Gerngross on the basis of the water column: 1 meter water column would correspond to the pressure of the water in 1 meter of water depth at a temperature of $4^{\circ}$ C. Accordingly, the air pressure generated by whispering was 30 meters, whereas voices with average amplitude reached 160 meters and voices with high to very high amplitudes amounted to 200-945 meters. In another system of measurement, which also used air pressure as an indicator, the amount of the voice's work was measured in ERG (derived from the Greek, $\varepsilon \rho \gamma o v$ ): "When giving a speech in a big room, the work of the voice [..] in women is four times lower than in men", Vsevolodsky-Gerngross wrote (1922, p. 18). One can see that at the dawn of electronic voice transmission, the physical concept of "work" (calculated as energy: force $\times$ distance) had social connotations: It was claimed that a male speaker was doing four times more work than a female speaker by using the greater voice power in his speech.

In the spirit of Rousseau, Vsevolodsky-Gerngross defined the main element of the voice - that is, vowels - from the "sensual cries of animals and the first voices of our ancestors". Such cries 
were said to require "the strongest tension in the muscles of the larynx" and "the highest pressure of the exhaled voice". The mouth of an ancient hunter was said to have been always open in contrast to the modern human mouth; accordingly, the emitted sounds were characterized by an enormous intensity. Over time, the sensual exclamation of the primitive man has been transformed into vowels which degree of vocality varied greatly: In this context, Vsevolodsky-Gerngross quoted one of the leading professors of the Institute of the Living Word, Lev Shcherba, who calculated the relative frequencies of Russian vowels in Hertz as follows: U - 432, O - 756, A - 980, Y - 996, E - 1816 and I - 3044 (1922, p. 37).

The idea that the sounds of modern language are derived from an acoustic invariance of the ancestral language led Vsevolodsky-Gerngross to drawing a relation between the vowels of the Russian language and vocally transmitted emotional states of ancestors: "With the vowel 'A' one will always feel optimistic and calm. ' $U$ ' seems scary, fearsome, terrifying and horrendous. 'I' seems painfully cramped" (Vsevolodsky-Gerngross, 1922, p. 101). Thus the similarity between the sounds of the natural soundscape and sounds of human speech acquired in the linguistic theories of the Institute of Living Word starkly ontological, Darwinian overtones.

\section{Strong voices and shared emotions}

The linkage between expressiveness of voice and the physical concept of work was important for the whole interwar period of radio broadcasting. Frightening, fearful and happy voices formed an acoustic matrix of social communication transmitted via radio. The relationships between perpetrators and victims of violence, deliberate action and passive suffering were also displayed symbolically in sound films by the contrast between dark male monster voices and shrill female voices. Both scary and scared voices can trigger acoustic chain reactions: one hears a terrifying voice and starts screaming in fear, infecting other people around with the sense of panic (Blumstein, 1992, p. 26). What exactly is the qualitative difference between aggression- and fear-driven vocal expressions? In the animal kingdom, the aggression-driven signals are generally extremely intensive. Although most predators hunt silently (Gil-da-Costa, Palleroni, Hauser, Touchton, \& Kelley, 2003, p. 605), the use of acoustic signals with a high sound pressure for breaking the resistance of an adversary is not unheard of: before attacking, a lion paralyzes its chosen prey for 2-4 seconds with an intimidating roar and then usually attacks it mutely. Rattlesnakes, too, use low-frequency rattling sounds of its tail to paralyze prey.

Among humans, the aggression-driven vocal expressions generally have a higher intensity level as well. With the same amount of energy expended, the auditory sensitivity of the human ear is higher in the frequency range of the female soprano voice and lower in the area of the male bass voice. A voice with a basic frequency in the soprano range is clearly audible even if it is produced at temperate room volume. In contrast, a person with a deep voice has to use more force to be heard. Therefore male voices often sound more powerful, dominant and even more aggressive than female voices in normal speech. A man talking in a high falsetto, however, would be perceived as impotent or homosexual. Generally male force is considered to be emanated by a voluminous bass voice. Fearful voices however, need less energy. When men are scared, their voices come up into the upper frequency range. Horror dampens speech to whisper; nose and upper lips are drawn upward. Fearful female voices with higher fundamental frequencies come across as particularly penetrating. Analogous to exasperated reactions to the cries of women, most people have goose bumps when they hear the high-pitched whirring of the dentist's drill or the screeching sound of train brakes.

Epistemologically the effects of rage-driven and fearful vocal expressions were recognized by distinction between ethos and pathos in the Roman rhetoric tradition. The Institutio Oratoria of Quintilian points out that ethos communicates mild emotions, such as love and affection, that it 
has certain continuity and is often articulated in the context of comedy. In contrast, pathos is determined for expressing strong non-manageable affects, such as anger and fear. It possesses an immediate simultaneous effect and appears particularly in tragedies.

\begin{tabular}{|c|c|c|}
\hline Ethos & Pathos & Quintilian: Institutio Oratoria (VI 2) \\
\hline Calming effect & Stimulating effect & $\begin{array}{l}\text { Pathos perturbs ... Ethos is set to appease [lat.: } \pi \alpha \dot{\alpha} \theta \text { o } \varsigma \text { concitavit, } \\
{ }^{\top} \mathrm{H} \theta \text { o } \varsigma \text { solet mitigare] }\end{array}$ \\
\hline Weak emotions & $\begin{array}{l}\text { Strong effects: } \\
\text { rage; fear }\end{array}$ & [Pathos] is stronger, Ethos is weaker [lat. illud maius sit, hoc minus] \\
\hline Steady & Transient & $\begin{array}{l}\text { Ethos is steady, pathos is fleeting [lat.: ... ' }{ }^{\top} \mathrm{H} \theta \mathrm{o} \varsigma \text { perpetuum, } \pi \alpha \dot{\alpha} \theta \varsigma \varsigma \\
\text { temporale esse] }\end{array}$ \\
\hline $\begin{array}{l}\text { Context of } \\
\text { comedy }\end{array}$ & Context of tragedy & $\begin{array}{l}\text { [Ethos] is appropriate in a comedy, [pathos] is more like a tragedy }[\ldots \\
\text { illud comoediae, hoc tragoediae magis simile] }\end{array}$ \\
\hline
\end{tabular}

At the beginning of the twentieth century, guidelines for actors devoted much attention to the details of the acoustic expression of rage and fear. Acoustic manifestations of aggression, rage and anger originate in the lower chest register: "Muscles and nerves are tensed to the utmost, canines are displayed. In this effort, the voice often sounds hoarse and slow" (Winds, 1919, p. 104). In contrast, fearful voices are formed in the head register: "Fright flashes through the body like an electric shock, the mouth is torn open frantically", and "the loud, often shrill scream is wrested from it" (Winds, 1919). Because of the particular susceptibility of the ear to screams, the "scream queen" is still is one of the staples of horror films. The character represented by shrill screaming is usually a seductive woman who is afraid of becoming a victim of rape and male violence. As for classical theater, the corresponding role was defined as "damsel in distress." It is not surprising that the first "scream queens" began their career on stage: one could mention Olga Baclanova, also known as the "Russian Tigress", in the role of the cruel circus dancer Cleopatra in Tod Browning's horror film Freaks (1932) (Mank, 1999, p. 118), Madge Bellamy playing young woman transformed into a zombie by an evil voodoo master in Victor Halperin's horror film White Zombie (1932), ${ }^{1}$ Carroll Borland in the role of pseudo-vampire Luna in Tod Browning's Mark of the vampire (1935) (Guiley, 2005, p. 37), Elizabeth Allan as young Daisy from the telephone switchboard in Hitchcock's The Phantom Fiend (or Lodger) (1932) (Svehla \& Svehla, 2000, pp. 12-18), and finally Virginia Bruce, who impersonated Jane Eyre in a sound film adaptation of Charlotte Bronte's novel of the same title, etc. In the second group of scream queens, we can find actresses who almost exclusively are known as sound film actresses, such as Fay Wray, who became famous for her screams in King Kong (1933), Janet Leigh in Hitchcock's Psycho (1960), Jamie Lee Curtis in John Carpenter's Halloween (1978) and finally Drew Barrymore in Wes Craven's Scream (1996). They all doubtlessly helped those horror thrillers to become unprecedented box-office successes (O'Brien, 2008, p. xii). ${ }^{2}$

In her article Exorcising the devil, Josephine Woll (2004) acknowledges that Soviet cinema avoided horror films for the most of its history: terror and shriek contradicted almost every major tenet of Marxist historical materialism. The Soviet state had little use for the tragic view. It is symptomatic that the word "kriklivyj" (inclined to screaming) has established itself as a negative label of decadent phenomena in Western aesthetics. In this regard, it should be recalled that Stalin reacted with disbelief at the unusual mode of speaking and singing in Shostakovich's opera Lady Macbeth of the Mcensk district: In the infamous article Sumbur vmesto muzyki (Muddle instead of music) informed by Stalin's anger and disgust, David Zaslavskii complained that "singing [was] replaced by screaming on the stage". Quite symptomatic was Maxim Gorky's definition of jazz as an art of "wildly whining, whistling, booming, howling, roaring and rattling sounds". In his polemical essay O muzyke tolstych (About the Music of the Fat People), Gorky 
described the uneven frequency spectra of jazz as tantamount to sexual perversions of the bourgeois world:

Suddenly some idiotic pounding hammer shatters the fragile silence [...] Then monstrous voices, reminiscent of the neighing of a horse, are added. You can hear the grunting of a copper pig, cries of a donkey and the horny croaking of a giant frog. $(1928$, p. 1)

Despite continuous attacks on cinematic screaming instigated by Bolshevik leaders, Soviet cinema still had its moments of horror during the 1930s and 1940s. The actress Ada Voitsik (1905-1982) might be regarded as one of the few scream queens or rather as one of the few victimized female figures on the Soviet film stage of the 1930s. Voitsik played in her husband Ivan Pyriev's film Konveyer smerti // Assembly line of death (1933) a poor working class girl Luisa who experienced loss of illusions. She also played an innocent girl Anna who had tough luck to marry a traitor in Pyriev's other thriller The party card // Partiyny bilet (1938, USSR, dir. Ivan Pyriev). Both Konveyer smerti and Partiyny bilet, in which Voitsik played the main parts, were forbidden and shelved: tragic actresses with sad eyes emulating the style of Vera Kholodnaya and Vera Karalli were getting out of fashion. Some of them had to change not only the genre but also the hair color - from brunette to blond: Blond movie stars, such as Liubov Orlova, Valentina Serova, Zoya Fedorova, and Janina Zheimo were supposed to play in comedies rather than in tragedies. Voices of new actresses had to be in line with the concept of Ethos, not Pathos. Ivan Pyriev, who also was a powerful director of Mosfilm has left his wife Ada Voitsik down, most probably because he believed he could not promote her any longer. He turned his attention to a more promising blond actress Marina Ladynina, whom he married soon after that.

The low number of screaming voices on the Soviet film stage could be explained by a combination of technical (low quality of Soviet microphones) and social (low prestige of aesthetic pathos) reasons. Sergey Eisenstein was probably the first to shock his listeners with uneven frequency spectra of screaming. He borrowed this technique from the aesthetics of German expressionism and used it together with grotesque camera angles, memorably distorted shadows. Adapting the sound effects of Hollywood to Soviet conditions, Eisenstein transformed a historical epic of Ivan the Terrible into a psychological horror film. Performing Elena Glinskaya (Ivan's mother) in this film, Voitsik exudes a shrill cry "I have been poisoned, I am dying, fear the poison, watch the boyars". The dark deformed shadows seen under low arches alluded to the uneven surfaces on the spectrogram that displays the acoustic characteristics of the screaming voice. Following up on the Hollywood style represented by King Kong (1933), Eisenstein applied dark colors to the figures of boyars - male monsters representing gravity, physical strength and sexual energy, while the screaming mother Glinskaya was depicted in white clothes on the floor. Voices that had greater amplitude were usually attached to figures located in the upper part of the cadre. In a similar manner, the roar of the heavy black gorilla in King Kong stood in a clearly vertically polarized relationship to the voice of an ethereal white woman who embodied the enervating effect of shrill dissonances.
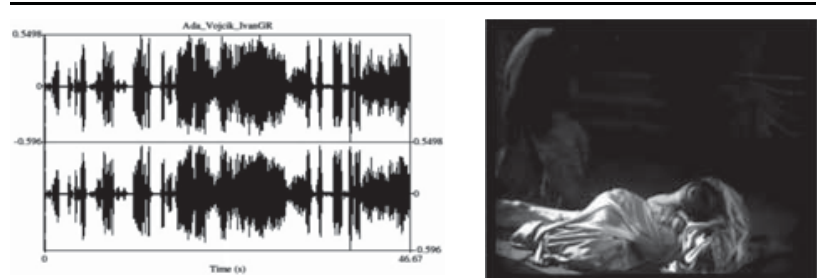

Eisenstein, Ivan the Terrible, 1945; Ada Voitsik as screaming Glinskaya 
While comparing Soviet and the American traditions of voice performance one should bear in mind the cinematic experiments with recorded scream occurred in very different types of gender communities. In the literature of the early and late Romanticism, the motif of female desire was expressed by the dynamic affect model of "femme fragile" versus "femme fatale" (or a vampire woman): passive and fragile would suddenly turn into active and seductive beasts. Innocence would become vice, and victims of violence would themselves exercise violence. The antithesis of "femme fragile" and "femme fatale" stood in the opera of the nineteenth century for the collision between regular bourgeois routines and the untamed forces of nature. Unique female vampires, opposed to their male counterparts, appeared in the works of Gustav Mossa, Etienne Csok, Dante Gabriel Rossetti at the end of the nineteenth century. With a synesthetic repertoire of the "scream queen" voice, the Western sound film answered the needs of a society, which has grown distrustful of the visible and sought authentic identity in acoustic characteristics (Borrmann, 2011, p. 288).

Things were quite different in the Soviet Union. The repertoire of Soviet film actresses reflected ethical attitudes of working women who knew their maternal and social obligations by heart. Stalin's bureaucracy saw traditional family as a useful tool for enforcing its policies, so in the thirties divorce became more difficult to obtain and abortions were banned except for medical reasons. This restrictions placed on abortion were caused mainly by the shortage of labor after World War I and the Civil War; their chief purpose was to increase the male population. At the same time, the government instructed women to learn "enjoying motherhood." Women with five children or more were freed from obligation to work, and mothers of more than nine children were awarded medals. The ascent of the voice to an emotional octave would not have fit well with the promoted stereotype of a working woman and militant mother. A chirping voice would have seemed too frivolous and playful in an epic film although it was still considered appropriate for a comedy.

It is noteworthy that the first Soviet horror film Viy (based on a story by Nikolai Gogol and directed by Pyriev's pupils Georgi Korpachyov and Konstantin Ershov) appeared only in 1967. This movie did feature a screaming vampire woman, but the voice of the actress Natalia Varley who played the witch in question was replaced by the much higher off-camera voice belonging to the Soviet animation artist Klara Rumyanova. Such an otherwise very unusual maneuver for Soviet sound film was apparently necessary to stage an unleashed female affect in the most conventional way. Rumyanova's high-pitched voice was a signature reference to fairly-tale protagonists of animation films for children such as Cheburashka, the little rabbit from the legendary Soviet comic series Rabbit and wolf, and the little boy from the famous cartoon Karlsson and the little boy. Staging Rumianova's voice, sound directors were obviously at pains to style the first Soviet horror film containing sexual connotations as a trivial fairy tale.

Starting from the 1970s, there was an observable trend in Soviet cinema toward the use of screaming for displaying strong emotions. However, this was allowed mainly in the context of epic genres. A terrifying cry might be a feature of a woman paralyzed by grief, as was the case with Sergei Kolosov's film Pomni imja svoe (Do not Forget your Name) (1974), where Liudmila Kasatkina played a woman in a German concentration camp was forced to part with her son selected by the Nazi camp for administration for inhuman medical experiments. Although staging of scared voices was untypical for the mainstream films, Soviet sound directors became increasingly keen to display grief-stricken voices of suffering women. Beyond this pathos-oriented frame, the ideal of a working spouse and militant mother remained persistent during the whole period of Soviet history. Voices that corresponded to this ideal had to remain controlled and balanced: Liudmila Kasatkina herself symptomatically gained popularity as a calm smooth offcamera voice of the black panther Bagira in the acclaimed cartoon series Maugli (1967-1971). 
In contrast, the cinema of Stalin's period mainly featured female heroines who possessed bright voices with a large pitch range, a big number of voice breaks and a fast speech rate. In terms of sensory perception, voices with these characteristics are normally perceived as happy voices (happy bonnie). Brightness presupposes that the voice is being formed not in the chest but in the head register. Bright voices usually need less energy than the voices built in the chest register, for energy usually comes from the air ejected from the lungs. Only a reduced fraction of the vocal fold mass vibrates with a voice built in head register. Young Soviet actresses of the thirties, who were aware of the unsatisfactory quality of microphones, were trained to pronounce all the stressed vowels in a very intensive way, because they knew that extra power in the high harmonics would make their voices bright and clear. Their voices contain a large fraction of locally unvoiced frames (up to 50\%) as well as a large number of voice breaks (all inter-pulse intervals longer than 16.6667 milliseconds are regarded as voice breaks). Breaks are needed to pump air from the lungs and this need explains the effect of the chirping, tweeting voices that give an impression of a vital, enthusiastic mood. Such temper was in line with the repertoire of ingénue, inherited from the classical stage. Ingénue means generally a girl or a young woman who is naive, endearingly innocent and wholesome. Roles played by Liubov Orlova in Volga Volga (1938, USSR), Valentina Serova and Emma Tsesarskaya in Devushka speshit na svi danie // Late for a date (1936, USSR), Janina Zheimo in Zolushka / Cinderella (1947, USSR) matched the repertoire of ingénues that extolled the happiness of life in the Soviet country.

\begin{tabular}{lcccc}
\hline Actress & $\begin{array}{c}\text { Min pitch } \\
(\mathrm{Hz})\end{array}$ & $\begin{array}{c}\text { Max pitch } \\
(\mathrm{Hz})\end{array}$ & $\begin{array}{c}\text { Median pitch } \\
(\mathrm{Hz})\end{array}$ & $\begin{array}{c}\text { Voice breaks } \\
(\%)\end{array}$ \\
\hline $\begin{array}{l}\text { Lubov Orlova, in Volga Volga }(1938) \\
\text { Valentina Serova in Late for a date }\end{array}$ & 168 & 522 & 353 & 53 \\
$\quad(1936)$ & 198 & 523 & 353 & 41 \\
$\begin{array}{l}\text { Emma Tsesarskaya in Late for a date } \\
\quad(1936)\end{array}$ & 87 & 526 & 415 & 45 \\
Janina Zheimo in Cinderella (1936) & 164 & 519 & 367 & 38 \\
\hline
\end{tabular}

The peculiarity of acoustic expression of female actresses in Soviet cinema of the 1960s1970s was not so much a high chirping or tweeting voice, but rather a breathy voice in conjunction with a relatively low basic frequency. The breathy voice is characterized by an incomplete glottis closure during phonation. A high degree of breathiness has the effect of an erotic voice (Eckert \& Laver, 1994, p. 73): Decisive for this eroticism is the rather slowly decreasing respiratory pressure, which is put in contrast to breath control. With almost whispering breathy voices formed in the chest register, Soviet actresses spoke the pathos formulas of female love which the millions of former Soviet viewers could recognize immediately and imitate years after the premiere.

To confirm the hypothesis about the dominance of low-pitched breathy female voices in the Soviet film dramas after WWII, the voices of the most prominent Soviet actresses of that time were evaluated using the frequency-measuring PRAAT program. From the series of female movie actresses that occupy places $1-771$ on the popularity list of the Internet platform "Ruskino.ru", the voices of the first twenty actresses were selected for pitch analysis. It appears that the fundamental frequency of the voices of the most popular actresses like Alisa Freyndlikh, Liudmila Gurchenko, Elina Bystritskaya, Nonna Mordiukova, Irina Muravieva, Margarita Terekhova and Ekaterina Vasilieva is well below the standard guideline value of 240 Herz (Pemberton, McCormack, \& Russell, 1998, p. 208). For Margarita Terekhova, Nonna 
Mordiukova and Liudmila Gurchenko the lower frequency values extend into the male baritone and bass registers.

\begin{tabular}{lccc}
\hline & \multicolumn{2}{c}{ Basic Frequency } \\
\cline { 2 - 4 } Actresses & Average & Standard variance & Minimum \\
\hline Margarita Terekhova & $227 \mathrm{~Hz}(<240)$ & $115 \mathrm{~Hz}$ & $82 \mathrm{~Hz}$ \\
Nonna Mordiukova & $195 \mathrm{~Hz}(<240)$ & $65 \mathrm{~Hz}$ & $125 \mathrm{~Hz}$ \\
Liudmila Gurchenko & $168 \mathrm{~Hz}(<240)$ & $70 \mathrm{~Hz}$ & $75 \mathrm{~Hz}$ \\
\hline
\end{tabular}

It should not be forgotten that unlike the chirpy voices of the $30 \mathrm{~s}$, the breathy voices of the $60 \mathrm{~s}$ and 70 s were increasingly transported into private apartments by means of television: the television transformed chirpy public voices of Soviet ingénues into more intimate bedroom voices. The trend toward low-pitched breathy voice transcended the boundaries of fictional genres. A number of highly popular TV programs and forecasts of the 1980s used along with breathiness the so called emphatic duration of vowels in order to create an atmosphere of openness and intimacy in the flats of the Soviet spectators.

Yulia Belianchikova (1940-2011), the longtime host of the program Zdorovye // Health for those seeking medical advice, was considered as a family member by millions of Soviet spectators. She possessed a very relaxed, slightly lisping voice of a low intensity. So when this voice passed away with its owner, some viewers associated this event with the collapse of the postSoviet health system. In a similar way, the popular TV presenter Valentina Leontieva (19232007) who hosted a program Ot vsey dushi // From the whole heart in which war heroes met their fellow soldiers, was popularly known as "aunt Valya". Leontieva possessed a low-pitched breathy voice and her oral presentations were characterized by the emphatic elongation of vowels: "aaat vseeey duushii"

Main changes in the style of vocal performance.

Female voices in Russian media

\begin{tabular}{ll}
\hline $19301950 \mathrm{~s}$ & $19601980 \mathrm{~s}$ \\
High pitch median & Low pitch median \\
Brightness & Breathiness \\
Head register & Chest register \\
Voice breaks & Voice flow \\
High intensity of stressed vowels & Emphatic elongation of stressed vowels
\end{tabular}

To conclude, I would stress the cross-fertilization of technological, social and cultural stereotypes that form acoustic cultures of particular communities (Hepp, 2013). So far, the Russian transition to sound has never been studied from a comparative perspective. How did sound media modify the traditional social functions of the voice? Which of the traditional interpretations of voice have been incorporated into the new sound media? In this article, I tried to give an answer to some of these questions. Sensations that were once viewed as dangerous, experienced extended social acceptance as the Western society reached a certain level of mutually expected self-control. Unlike in the West, in early Soviet mainstream film one could hardly find circumstances in which a female protagonist was a zombie, insatiable nymphomaniac or vampire woman. The voice repertoire of the Soviet mainstream film reflected ethical attitudes of a society that could not identify itself with the progressive emancipation of emotions. Although the acoustic cultures which were reviewed here developed independently, many similar features can be found: It is not so much the likeness of content but structural and formal similarity enhanced by formal similarity at times. To unlock the meaning of these parallels, both differences 
and similarities between acoustic cultures of Eastern and Western Europe should be studied in more detail.

\section{Disclosure statement}

No potential conflict of interest was reported by the author.

\section{Notes}

1. Rhodes (1997, p. 108) notes that "Bellamy has devoted two years to the spoken stage with a view to obtaining vocal training for the talkies".

2. Interestingly, the British public was not always favorable of the American horror films screams. The book Censored Screams describes the oppressive sobriety with which the British Board of Film Censors organization (BBFC) demanded extensive cuts by trying to enforce age restrictions. The board banned outright many horror films from Hollywood (Johnson, Gordon, \& Weaver, 2006, 58 ff.)

\section{References}

Anonymous. (1929). Nadezhnaia slyshimost na detektornyi priemnik [Reliable reception of detector recei vers]. Radioslushatel [Radio listener], no pagination.

Anoshchenko, N. (1930). Zvuchashchaya filma v SSSR $i$ za granicei [The sound film in the USSR and abroad]. Moscow: Teakinopechat.

Blumstein, D. (1992). Why did the peafowl scream? Functions of animal vocalizations. Natura World Wide Fund for Nature. Retrieved from https://www.eeb.ucla.edu/Faculty/Blumstein/pdf\%20reprints/ Blumstein1992 Natura Comm.pdf

Borrmann, N. (2011). Vampirismus. Der Biss zur Unsterblichkeit [The vampirism. Biting to eternal life]. München: Diederichs Verlag.

Chernyshev, V. (1912). V zashchitu zhivogo slova [In defense of the living word]. Sankt Peterburg: Glavnyi sklad $\mathrm{u}$ avtora.

Chown, E., \& Brandist, K. (2007). Iz istorii Instituta zhivogo slova: protokoly zasedanii [From the early history of the Institute for the living word: The meetings' protocols]. Novoe Literaturnoe Obozrenie, N 86. Retrieved from http://magazines.russ.ru/nlo/2007/86/ch6.html

Doctor, J. (1999). The BBC and ultra modern music, 1922 1936. Cambridge: Cambridge University Press.

Eckert, H., \& Laver, J. (1994). Menschen und ihre Stimmen. Aspekte der vokalen Kommunikation [People and their voices: Aspects of the vocal communication]. Weinheim: Psychologie Verlags Union.

Gil da Costa, R., Palleroni, A., Hauser, M. D., Touchton, J., \& Kelley, J. P. (2003). Rapid acquisition of an alarm response by a neo tropical primate to a newly introduced avian predator. Proceedings of the Royal Society B, 270, 605610.

Gorky, M. (1928). O Muzyke tolstykh [On the music of fat people]. Pravda, 90, 18.4., 1.

Gradoll, D., \& Swann, J. (1989). Gender voices. Cambridge: Wiley Blackwell.

Guiley, R. (2005). The encyclopedia of vampires, werewolves and other monsters. New York, NY: Visionary Living.

Hepp, A. (2013). Cultures of mediatization. Cambridge: Polity.

Hilmes, M. (1997). Radio voices: American broadcasting, 1922 1952. Minneapolis: Minnesota Press.

Johnson, T., Gordon, R., \& Weaver, T. (2006). Censored screams. The British ban on Hollywood horror in the thirties. McFarland: McFarland\&Co Inc Pub.

Kozlov, L. (1996). Nekotorye uroki rezhissury [Some lessons of film directing]. Kinovedcheskie zapiski, 27, 7692.

Krassovsky, S. (1906). O yazykakh i nravakh. O dushevnykh oshchushcheniyakh, sviazannykh s chlenoraz delnymi zvukami [About languages and customs. About emotions tied to articulate sounds]. Sankt Peterburg: M. Ginsburg.

Lovell, S. (2015). Russia in the microphone age. A history of Soviet radio, 1919 1970. Oxford: Oxford University Press.

Lundby, K. (Ed.). (2014). Mediatization of communication (Handbooks of communication science, Vol. 21). Berlin: De Gruyter Mouton.

O’Brien, S. (2008). Virginia bruce. Under my skin. Albany, NY: BearManor Media. 
Ong, W. (1982). Orality and literacy. The technologizing of the word. London: Methuen \& Co.

Ozarovsky, Y. (1900). Nashe dramaticheskoe obrazovanie (Our theatrical education). Sankt Peterburg: Trud.

Pemberton, C., McCormack, P., \& Russell, A. (1998). Have women's voices lowered across time? A cross sectional study of Australian women's voices. Journal of Voice, 12(2), 208213.

Radioslushatel (Radio listener). (1929). no pagination.

Radioslushatel (Radio listener). (1930). no pagination.

Rhodes, G. (1997). White zombie. Anatomy of a horror film. California: McFarland.

Savva, V. (1901). Moskovskie tsari i vizantijskie basilevsy [Moscovite czars and byzantine basileus']. Kharkov: M. Silberberg i synovia.

Skorokhodov, G. (2004). Tainy grammofona [Mysteries of grammophone]. Moskva: Eksmo. Algoritm.

Svehla, G., \& Svehla S. (2000). Hollywoods classic scream queens. Baltimore, MD: Midnight Marquee Pr Inc.

Taranova, E. (2010). Levitan. Golos Stalina [Levitan. The voice of stalin]. Moskva: Partner.

Uspensky, B. (1988). Otnoshenie k grammatike i ritorike v Drevney Rusi v 1617 vv [The attitude towards grammar and rhetoric in old Russian in the 16th and 17th centuries]. In B. Uspenskij (Ed.), Literatura $i$ iskusstvo $v$ sisteme kultury [Literature and art in the system of culture] (pp. 208 224). Moskva: Nauka.

Uspensky, B., \& Zhivov, V. M. (2004). Tsar i Bog: Semioticheskie aspekty sakralizatsii monarkha v Rossii [The Czar and the god: Semiotic aspects of a monarch's sacralization in Russia]. In B. Uspenskiii (Ed.), Izbrannye trudy [Selected writings] (pp. 110 218). Moskva: Iazyki russkoi kultury.

Volkonsky, S. (1913). Vyrazitelnoe slovo [The expressive word]. Sankt Peterburg: Sirius.

Volkov Lanit, P. (1939). Golos Lenina na plastinke [Lenin's voice on a vinyl record]. Tekhnika molodezhi, 1, 9.

Vsevolodsky Gerngross, V. (1922). Teoriya russkoy rechevoy intonatsii [The theory of Russian speech into nation]. Sankt Peterburg: Gosizdat.

Winds, A. 1919. Die Technik der Schauspielkunst [The technique of acting]. Dresden: H. Minden.

Wittlinger, I., \& Sendlmeier, W. (2005). Stimme und Sprechweise erfolgreicher Frauen eine akustische und auditive Analyse [The voice and oral expression of successful women]. In W. Sendlmeier (Ed.), Sprechwirkung Sprechstile in Funk und Fernsehen [The impact of speech: Styles of speaking in radio and television] (pp. 71 121). Berlin: Logos.

Yakubinsky, L. (1919). Evolutsiya rechi. Stenogramma lektsiy, chitannykh v Institute Zhivogo Slova v $1919 \mathrm{~g}$ [The evolution of speech: Stenographic record of the lectures given at the Institute of Living Wiord in 1919]. Petrograd: Institut Zhivogo Slova.

Zapiski Instituta Zhivogo Slova. (1919). Petrograd (Original: Записки Института живого слова. Петроград. 1919).

Zakharine, D. (2005). Von Angesicht zu Angesicht. Der Wandel direkter Kommunikation in der ost und westeuropäischen Neuzeit [Face to face: Evolution of direct communication in eastern and western modernity]. Konstanz: UVK. 